\title{
Developing the Basic English Language Skills in Nigerian Colleges of Education: A Case Study of Three Colleges of Education
}

\author{
Oris Tom-Lawyer \\ School of Journalism, Language and Communication, University of Central Lancashire, Preston, UK \\ E-mail: ootom-lawyer@uclan.ac.uk
}

Received: 19-11-2015

Published: 01-05-2016
Accepted: 06-02-2016

doi:10.7575/aiac.ijalel.v.5n.3p.99
Advance Access Published: March 2016

URL: http://dx.doi.org/10.7575/aiac.ijalel.v.5n.3p.99

\begin{abstract}
This paper examines the pedagogies employed in developing the Basic English language skills in Nigerian Colleges of Education, with particular reference to three colleges. It investigates the adequacy of the English language skills in the preparation of the Nigeria Certificate in Education (NCE) English language teachers as the poor performance of Nigerian students in external English language examinations has become a source of concern to educational stakeholders (Patrick, Sui, Didam \& Ojo, 2014). The Nigeria Certificate in Education is the principal qualification for teaching in Nigeria (National Policy Brief, 2005). The paper constitutes a section of a larger study that evaluated the implementation of the NCE English Language curriculum. The Context, Input, Process and Product (CIPP) Evaluation model is the theoretical framework in the study. A mixed methods approach was adopted within the CIPP framework, while utilizing a case study. Twenty lecturers and one hundred and twenty students from three Colleges of Education comprise the sample drawn through multistage and purposive sampling. The instruments were documentary reviews, observation checklists, interviews, questionnaires and field notes. The methods of analysis were thematic content analysis and descriptive/ inferential analysis. The study revealed that lecturers do not adopt contemporary and appropriate pedagogy for the teaching of the four language skills. It recommends this aspect should be re-considered. Similarly, an immediate review of the Practical Listening Skills and Speech work aspect of the course outline is required as the lecturers have noted that it is abstract.
\end{abstract}

Keywords: English Language, Basic Language skill, College of Education

\section{Introduction}

The Nigeria Certificate in Education is the principal qualification for teaching in Nigeria (National Policy Brief, 2005).The graduates of the programme are qualified to teach the first nine years of schooling in the country. Recently, the National Commission for Colleges of Education reviewed the Minimum Standards (Curriculum) for Colleges of Education (NCE Implementation Framework, 2012). The review established a new structure, alongside some courses for the NCE programmes. This paper is concerned with the Junior Secondary School (JSS) English Language programme. One of the objectives of the programme is to 'develop the four language skills; listening, speaking, reading and writing for communicative purposes' (NCE Minimum Standards for Languages, 2012, p. 32). However, the poor performance of Nigerian students in external English language examinations has become a source of concern to educational stakeholders (Patrick, Sui, Didam \& Ojo, 2014). The achievement of this objective by the teacher trainees requires the collaborative efforts of all educational stakeholders of the programme as it is critical for the success of junior secondary students in English language. This is consequent upon the fact that the success of the (secondary) students in English language is dependent on the ability of their teachers to enable them acquire the four language skills (Aduwa \& Iyamu, 2006). Earlier studies have indicated that teacher trainees are non-competent users of the language (Obadare, 2011) and that students lack proficiency in the four language skills (Olaofe, n.d). This study empirically examines the development of the four language skills by Colleges of Education students.

\section{Literature Review}

\subsection{PESTLE Analysis of Nigerian Colleges of Education}

The mnemonic PESTLE signifies Political, Economic, Social, Technological, Legal and Environmental factors. The PESTLE analysis is a tool employed to analyse the environment of an organization. A literature review was conducted to determine the socio-cultural context of the English language programme of the Nigeria Certificate in Education in order to highlight the factors that inhibit the development of the four language skills.

\subsubsection{Political}

There are 82 Colleges of Education in Nigeria, comprising 22 Federal, 46 States and 14 private colleges (NCCE, 2009). This means that there are diverse learning providers. The colleges have been privatised, which means private individuals have the autonomy to establish Colleges of Education. Findings have revealed that the privatisation of 
education occurred in Nigeria between 1980 and 1990, by the granting of licenses to individuals to manage elementary, secondary and tertiary schools (Kalama, Charles, John \& Etebu, 2011). Full participation of the private sector in tertiary education obtained for the first time in 1999 (Okwu, Obiakor, Oluwalaiye \& Obiwuru, 2011). The granting of licenses to individuals stemmed from the fact that the government failed to manage the schools adequately.

The management of the schools is a corollary of the underfunding of the schools by the government (Ajelayemi, 2005, p. 2). Presently, the colleges are beset by labour unrest; the current strike (2013-2014) by the lecturers is worsening the situation of the colleges as the latest talks held between the government and the lecturers ended in a deadlock. Reports show that the students of Colleges of Education "have lamented the on-going nationwide strike by the Colleges of Education Academic Staff Union, COEASU, calling for an end to it' (Mohammed, 2014, p.1).

The implementation of educational policies is a challenge in the Nigerian higher institutions. It has been asserted that policy makers, who have a vision for the country formulate policies, which are seldom translated into practice by the implementers (Anyakoha, 1994; Obebe, 1983; cited in Asiyai, 2013). The factors that hinder the translation of such policies into reality are inadequate funding and inexpedient use of funds by implementing agents (Asiyai, 2013).

Poor leadership at the level of the government and at the level of the colleges is another problem that besets the colleges as the government is not committed to the development of education in the country (Asiyai, 2013).

\subsubsection{Economic}

The economy of Nigeria has witnessed a downturn as a result of the fall in oil revenues. Even though education had been given priority by previous administrations (Moja, 2000), the spending on education has not been high as the percentage allocation to the sector in expenditure by government ranges from $0.08 \%$ to $6.21 \%$ from 1970 to 2004 respectively and this has drastically affected the colleges. In the year 2000, it was reported by the Central Bank of Nigeria that insufficient funding is the blight of the educational sector in the country (Omojimite, 2010). Figures have shown that the spending of the Federal Government on education had dwindled. In 1996, it was $12.32 \%$, while it dropped to 7.0 in 2000. Table 1 is a comparison of the spending of Nigeria and some other European countries on education.

Table 1. Spending on Education (\% GNP) for some European Countries as compared to Nigeria in 2010

\begin{tabular}{ll}
\hline Country & $\%$ GNP \\
\hline Nigeria & 0.96 \\
\hline Sweden & 7.00 \\
\hline Finland & 6.80 \\
\hline Norway & 6.90 \\
\hline United Kingdom & 6.20 \\
\hline France & 5.90
\end{tabular}

Note: Extracted from The World Fact Book (Central Intelligence Agency)

https://www.cia.gov/library/publications/the-factbook/rankorder/2206rank.html and Country Snapshot: Nigeria http://www.gesci.org/assets/files/Country\%20Snap\%20Shot\%20Nigeria.pdf.

The figures above show that the Nigerian government is not allocating enough funds to the education sector. The reasons that have been deduced for the poor allocation of funds include:

- The fall in oil revenue since 2005;

- The prolonged military rule in the country that prioritized defence over education;

- The issue of corruption amongst school managers (Omojimite, 2010);

A direct consequence of this factor is the poor infrastructure in the colleges (Adekola, 2007). The poor infrastructure is a major cause of the poor quality of graduates from the schools. Brain drain (the migration of Nigerian academics to the western world in search of green pastures) is one of the factors protested against by the lecturers. Poor conditions of service and remuneration, which have resulted in low motivation, have caused some of the lecturers to migrate to other countries (Ibidapo, 2007). It has been noted that 'there is diminishing scope of mentoring junior researchers by seasoned and senior lecturers in Nigeria $[\mathrm{sic}]$ due to brain drain and that it has led to decline in research outputs from institutions of higher learning in Nigeria' (Asiyai, 2013, p.168).

Table 2 below shows the fall in faculty staff in tertiary institutions in Nigeria (with particular reference to Colleges of Education), which is noteworthy because a high proportion of staff is needed. The shortfall was exacerbated by 'inter and intra- sectoral brain drain, which have implications for quality teaching and learning' (Shu'ara, 2010, p. 14). 
Table 2. Faculty Staff in Nigerian Tertiary Institutions

\begin{tabular}{lccc}
\hline \multicolumn{2}{l}{ Faculty Staff in Tertiary Institutions } & & \\
\hline System Academic & & No. Required & Shortfall \\
\hline Colleges of Education & 11,256 & 26,114 & $14,858 \quad(56.9 \%)$ \\
\hline National Teacher Institute & 6,526 & 7000 & $474(06.8 \%)$ \\
\hline Poly/Monothenics & 12,938 & 30.016 & $17,078(56.9 \%)$ \\
\hline Universities & 30,452 & 50,000 & $19,548(39.1)$ \\
\hline NOUN & 5,220 & 15,000 & $9,780(65.2 \%)$
\end{tabular}

Source: 2007 System Wide Audit, cited in Shu'ara, (2010)

The economic situation also has its unpropitious effects on the students as some of them have to fend for themselves. This makes studying a difficult engagement. The students instead of concentrating on their studies have to make ends meet.

\subsubsection{Social Factor}

A perennial problem that plagues the colleges is the issue of cultism. The cults that operate in Nigerian tertiary institutions are secret cults, who engage in 'nocturnal initiation, ceremonies, drug use, extortion, rape, maiming, stealing, arson, examination malpractices, and murder' (Amaele, 2013, p. 35), which has infiltrated the various campuses in Nigeria. The emergence of cults has been blamed on the prevailing circumstances in higher institutions in Nigeria. The prevailing conditions have been identified as 'overcrowding, deteriorated facilities, admission malpractice and inadequately challenging academic programmes' (Moja, 2000, p. 42). The operations of the cult members cause most students, lecturers' families to live in terror as the cult members indulge in robbery, abduction, killings and destruction of infrastructure (Asiyai, 2013).

In Tai Solarin College of Education, 26 students were expelled for their role in cult activities (Kayode-Adedeji, 2013). This problem has affected the teaching and learning quality, the integrity of the students and dented the image of the institutions (Amaele, 2013).

\subsubsection{Technological}

When compared with Britain and other advanced countries, Nigeria has not made remarkable progress in the use of technology at all levels of Education (Iyamu \& Aduwa Ogiegbaen, 2005). The Global Information Technology (2005) with the use of Networked Readiness Index (NRI) has been identified by Adedeji (2012) as a method that measures the level of preparedness of a country to partake and benefit from the developments of ICT. It was discovered that out of the 115 economies measured; Nigeria ranked $90^{\text {th }}$. Similarly, in 2004 , out of 104 countries, it ranked $86^{\text {th }}$. In other words, the level of Nigeria's preparedness is low, showing a low level of preparedness.

The problem of teaching and learning in Colleges of Education in Nigeria has been noted as access to ICT and its use in the enhancement of the teaching/ learning process (Onasanya et al., 2010, cited in Garba, Singh, Yusuf \& Ziden, 2013). In addition, mere observation of Colleges of Education lecturers revealed that most of them depend on the conventional non-electric form of teaching (Ajayi, 2008). The findings of a study carried out by Ajayi (2008) revealed the nonavailability of internet, projectors, electronic mail, electronic notice boards in Colleges of Education. The reasons adduced for this were insufficient supply of ICT facilities and the incompetence of the lecturers in the use of the facilities.

Moreover, it was observed that the capacity for ICT usage in the schools was poor. The problems associated with this as viewed by the lecturers were 'epileptic (erratic) supply of electricity, lack of support for integration of ICT in teaching, inadequate ICT materials, lack of internet outlet in the classrooms and expensive nature of ICT' (Ajayi, 2008, p. 213).

In another study conducted by Adedeji (2011) on the Availability and Use of ICT in South-Western Colleges of Education, it was discovered that six colleges had no computer(s) centres and the lecturers also had no access to computers. Colleges that had computer laboratories possessed outdated personal computers.

In conclusion, to corroborate the aforementioned points, according to Kwache (2007), some of the problems militating against ICT implementation in the educational system of the country include:

- $\quad$ Lack of Skilled ICT Personnel: most lecturers in the different institutions are not computer literate and they lack specialists responsible for the management of ICT facilities.

- Equipment Cost: the economy of Nigeria has suffered recession over the past years, so there are limited funds for the procurement of the necessary equipment (Itegboje \& Okubote, 2012).

- Attitude of the Management of most Institutions: the government does not aid the development of ICT facilities and the management of most institutions are not curious about it (Albirin, 2006).

- The Erratic Power Supply: The erratic power supply suffered by the nation is a perpetual problem as most parts of the country lack electricity supply.

These are fundamental problems that need proactive solutions. 


\subsubsection{Legal}

The Act establishing Federal Colleges of Education was enacted in March, 1986.The Act stipulates that the colleges are to provide 'full time courses in teaching, instruction and training in technology, applied science, commerce, arts, social sciences, humanities and management'(Federal Colleges of Education Act, 1986, No. 4). The different state colleges have other Acts that enforced their existence.

For the implementation of the Act stated above, another Act establishing the National Commission for Colleges of Education was established on $17^{\text {th }}$ January 1987. The Body was empowered to advise the Federal Government of Nigeria on education matters that do not fall within the jurisdiction of universities and Polythenics (National Commission for Colleges of Education Act, 1989). The Commission regulates the review of the curricula of the colleges and accredits their courses. The Act also provides for other offices; provost, deputy provost, governing council, registrar, and principal officers of the colleges. The mandate of the NCCE has been succinctly stated 'to include supervision, coordination and the setting of minimum standards for general administration, leadership, academic programmes, facilities, teacher qualification, teacher-student ratio, teacher motivation, salary advancement etc'(EmeUche, 2006, p. 3).

The inadequate performance of the NCCE in enforcing the minimum standards with regard to 'facilities, teacher quality, curriculum implementation, teacher-student ratio etc' has been described as an impediment to the implementation of the curriculum; furthermore, the accreditation exercises have been coloured with politicization (EmeUche, 2006, p. 9). The quality of students admitted into the colleges has been a controversial topic (Akinbote, 2000; cited in Akinbote, 2007) and the appointments of provosts and other senior administrative staff have been politicized (Eme-Uche, 2006).

\subsubsection{Environmental}

The tertiary institutions in Nigeria (amounting to 50\%) have been reported to possess a large student population (Ezra, Bijimi \& Aliba, 2013). This factor has implications for the environmental conditions of Colleges of Education in Nigeria. The accommodation of students in Colleges of Education is a condition that is fraught with difficulties as the problems range from inadequate accommodation to poor sanitary conditions: 'the psychological, physiological, facility and security requirements have been identified as four important qualitative needs that measure the adequacy and habituality of student housing' (Ezra, Bijimi \& Aliba, 2013, p. 29). The inadequacy of hostel accommodation in the institutions will impact on the academic achievements of the students. These needs have to be effectively provided for academic performance to be optimal.

However, it has been asserted that the figures of the National Commission of Colleges of Education have indicated that the availability of hostel accommodation in the colleges falls below $30 \%$ of the demands of the students (Ezra, Bijimi \& Aliba, 2013). In a study conducted by Eme-Uche (2006, p. 7) it was shown that in the colleges, school environment was seen as being insecure, unhealthy and unconducive for the learning/teaching process. In addition, 'there are no recreation facilities, adequate hostel accommodation and classroom and lecture halls' (ibid).

In another study that corroborates this point, the hostel accommodation of the students of Kaduna State College of Education was discovered to be unhealthy, poor and lacking facilities (Ezra, Bijimi \& Aliba, 2013). If the colleges are to produce quality teachers, the problem of environment needs to be considered.

\subsection{Developing the Four English Language Skills}

English language has attained the status of global-language as it is a 'must-learn' language. It portends a better future educational attainment, particularly for second language speakers. Therefore, students, who have limited proficiency in the language are striving to improve their knowledge of the language. The goal of a second language speaker is to be competent in English language and the basic skills of the language (Schelleker, 2011). S/he also acquires language for proficiency that will enable $\mathrm{h} / \mathrm{him}$ engage in purposeful communication (Uso-Juan \& Martinez-Flor, 2006; cited in Beltran, 2011). A language has four skills, which are reading, listening, speaking and writing. The first two skills are receptive, while the others are productive. The receptive and productive skills have been partially viewed as being passive and active respectively (Harmer, 2007). The concomitant of the skills are shown by two specifications: they are the communication mode: oral or written and the communication direction: receiving (SIL International, 1999). For effective study, developing the four language skills is a necessity. According to Williams (1973; cited in Azubike, 2007, p. 12)

In learning a language, it is not just the ability to make a sentence that matters,

what counts is the use to which that ability is put. A skill in itself is a tool.

Our real concern is not with being able to handle the language, but what we do with it

when we handle it. We are not concerned primarily, with learning about conditional

clauses but with the job of using them properly in the normal course of a conversation or business.

This implies that a second language learner of English language should be able to develop the four language skills for communicative competence. For a language to be effectively learnt, the four language skills need to be developed (Azubike, 2007). The pedagogies for the development of the skills should also be compatible with the language contexts of the learners. Similarly, they should be contemporary. One of the objectives of the NCE English Language 
Curriculum is to enable students develop the four language skills (Minimum Standards for Languages, 2012). The adequate development of these skills by NCE teacher trainees will be a reflection of the language competency of Junior High School students in the country. However, it has been asserted by Christopher (2008; cited in Agbatogun, 2013) that the mode of teaching English in (some) Nigerian schools fails to promote communicative competence in the language skills of the students.

\subsubsection{Listening Skill}

Scholars have noted the under-estimation of the listening skill as its teaching is not emphasized (Hedge, 2008; Field, 2008). This should not be the case because of its importance to the other skills. Early views of listening was on the mastery of micro skills such as sound discrimination deduction of uncommon words... (Rost, 1990). However, current practice for a listening lesson should entail 'pre-listening, extensive listening, intensive listening and post-listening' (Field, 2008, p. 17).This will to a large extent aid the second language learner of English.

\subsubsection{Writing Skill}

The objective of the second language educator of English is to produce skilled writers of the language. Writing is a process that requires strategies for effective composition. The imitation of good write-ups is laudable but a more appropriate method would be the process genre approach by Badger and White (2000). This involves the development of writing through various stages and its facilitation by teachers.

\subsubsection{Speaking Skill}

For the achievement of fluency in English, second language speakers 'will have to be speak in a range of different genres and situations, and they will have to be able to use a range of conversational and conversational repair strategies' (Harmer, 2007, p. 34; 3).This will enhance their development of the skill. A most probable process as proposed by Thornbury (2005) highlights awareness-raising activities, appropriation activities and towards autonomy.

\subsubsection{Reading Skill}

The reading skill is a stimulus for successful acquisition of knowledge in other subjects by the second language speaker. It demands intensive and extensive reading for optimal benefit in teaching (Harmer, 2007). There are different approaches to teaching reading. However, teacher trainees need to be taught the appropriate methodology for imparting the skill.

\subsubsection{Integration of the Skills}

The integration of the skills during classroom teaching has been advocated as it promotes natural interaction by the learners of the language, while a segregation of the skills will lead to deficiency in 'academic communication' (Salem, n.d, p. 1). In other words, the integration of the skills will enhance communication. Furthermore, integrating the skills will also afford students the opportunity to maximize their learning (Hammer, 2007).

\subsection{Attitude to Learning}

The attitude of students to learning is one factor that needs consideration in the teaching and learning process. The foremost predictors of the academic performance of students are motivation and attitude (Hendricks, 1997, cited in Bakar, Tarmizi, Mahyuddin, Elias, Luan \& Ayub, 2010). For a curriculum to be effectively implemented, students must have the right attitude to learning.

It is necessary to consider some definitions of the concept of 'attitude'. Scholars have different views of the word. According to Gardner (1985, pp, 91-93) 'attitude is an evaluative reaction to some referent or attitude object, inferred on the basis of the individual's belief or opinions about the referent. Therefore, Gardner (1985; cited in Soleiman \& Hanafi, 2013, p. 3817) asserted that 'attitude is thus linked to a person's values and beliefs and promotes or discourages the choices made in all realms of activity, whether academic or informal'. It is also 'the readiness to respond to a situation and an inclination to behave in a consistent manner toward an object' (Eveyik, 1999, p. 21). Another definition was also given by Baker (1992, cited in Alkaff, 2013, p.107) that attitude is 'a hypothetical construct used to explain the direction and persistence of human behaviour'.

The aforementioned definitions reveal the fact that attitude occurs in response to an object or situation and that an element of behaviour is reflected. To this researcher, a working definition would be a behaviour exhibited in response to a particular situation. Three aspects of attitude are cognitive, behavioural and emotional (Wenden, 1999). Findings from research have proved that the affective domain affects language learning twice as much as the cognitive domain (Stern 1983; Eveyik 1999; Skehan1989; Gardner 1985; Spolsky 1989, cited in Saracaloglu, n.d).

Some salient points about attitude towards learning are: that behaviour can be influenced by attitudes and that there is a relationship between achievement and attitude (Kaballa \& Crowley, 1985; Schibec \& Riley, 1986; Weinburgh, 1988; cited in Saracaloglu, n.d; Buschenhofen, 1998; Inal et al, 2003 cited in Alkaff, 2013.) which are not dependent on each other but relate in a complicated and unpredictable manner (Ajzen \& Fishbein, 1975 cited in Salome, 2013).

Attitudes can be positive or negative and a positive attitude to language and learning helps the desire to acquire it or facilitates its learning and it aids proficiency in the language (Chamber 1999; Gardner \& Lambert, 1972; cited in Saracaloglu, n.d); this fact was corroborated by Zimmerman, Bandura and Martinez-Pons (1992, cited in Bakar et al, 2010), when they reported a positively significant relationship between the achievement of students and their attitude. In addition, the success rate of students who possesses negative attitudes drops (Gunger, Acikgoz cited in Sen, 2013). 
However, Lennartsson (2008, p.7) has asserted that 'negative attitudes may also have a positive effect on L2 learning, if the learners have a strong will to learn a language'. Furthermore, students' attitudes can change from negative to positive and vice versa. Attitude cannot be disconnected from language and learning, because it affects performance. Attitude is associated with second language learning as it is a determinant of the behaviour of learners and its importance in second language learning has been noted by researchers (Alkaff, 2013). Research has also proved that a close relationship between attitude and motivation determines the successful acquisition of a language (Gardner \& Lambert, 1972; cited in Rahimi \& Hassani, 2011).

Students, teachers, parents, communities and nations have attitudes that may influence the teaching and learning process (Mill, 1960, p. 214). The importance of attitude can be seen in its close relation with study and its influence in language performance (Reid, 2003; Visser, 2008; cited in Abidan et al., 2012). It was noted by Holmes that 'people develop attitudes toward languages, which reflect their views about those who speak the languages and the contexts and functions with which they are associated' (Holmes, 1992; cited in Sadighi \& Zarafshan, 2006).

\section{Research Question}

- How does the implementation of the curriculum equip students to develop the four language skills? (Input Evaluation)

\section{Methodology}

The study is a type of mixed methods research (Blease \& Cohen, 1990). Mixed methodology research involves 'philosophical assumptions that guide the direction of the collection and analysis and the mixture of qualitative and quantitative approaches' (Creswell \& Clark, 2007, p. 5). In this study, the use of mixed methods research will strengthen the understanding of the phenomenon (Gay et al., 2006) as the use of a data source alone will not be adequate (Creswell \& Clark, 2011).

The three approaches in research design as proposed by Creswell (1994) are research approach, research strategy and research methods. The approaches in the design of this study are discussed below:

\subsection{Research Approach}

In developing the design of a study, four elements are considered; they are paradigm world view, theoretical lens, methodological approach and methods of data collection (Crotty, 1998). The paradigm for this study is pragmatism (it focuses on research consequences and its primary importance is based on questions asked instead of the methods). This informed the epistemology (practicality) that is collection of data to deal with research questions and the axiology, which includes subjective and objective perspectives.

The theoretical lens is a model (social science theory), which is the CIPP Evaluation framework. The methodological approach combines deductive and inductive thinking as mixed methods data are utilized (Creswell \& Clark, 2011), while the data collection methods are documentary reviews, interviews, questionnaires, field notes and checklists.

\subsection{Research Strategy}

This study is based on a case study approach (Blease \& Cohen, 1990), with the CIPP evaluation model as a theoretical framework. A case study focuses on a single case in order to show the significant characteristics about its quality. This study is an evaluative case study (Stenhouse, 1985). The rationales for adopting a case study approach are that it is apposite for programme evaluation, programmes are studied in their natural setting, all germane methods / sources of information are utilized and programmes are considered in detail (Shinkfield \& Stufflebeam, 2007; Yin, 2011).

\subsection{Research Methods}

A multistage sampling technique was used in this study because of the dispersion of the population in various cities across Nigeria (Bryman, 2008). To get the sample for this study, the first stage of sampling was cluster, this entailed dividing the country into clusters and it was into the six geo-political zones of Nigeria, where at least a College of Education can be found. This is phase one of the sampling procedure. The six geo-political zones are the south south, south west, south east, north west, north east and north central zones. The criterion for selection in this phase was that all the Colleges of Education fell into a geo-political zone in the country. At this stage, the Primary Sampling Units (PSUs) were based on the geographical zones.

Purposive Sampling was used to choose two zones in the south. They are the south west and the south-south comprising six states each. It was necessary to choose the two zones because there is a wide gap between schooling in northern and southern Nigeria. In addition, there are gaps in the enrolment of males and females in the country; the gaps in the enrolment of females and males are widely evident in the north (National Literacy Rates Survey, 2002) and there have also been reports of terrorist attack on the northern zone by Boko Haram (BBC, 2014). In the south south zone, some states could not be chosen for political reasons such as activities of militants in the areas (Risk Assessment Form, UCLAN, 2012).

The second stage was the delineation of the schools in the two zones into strata, using the stratified random sample. The schools were stratified into federal, state and private schools. This phase, which is the Secondary Sampling Units (SSUs), was based on type of school. The state schools were chosen using purposeful random sampling (Cohen et al., 2011). It was necessary to choose the state schools to give room for uniformity of choice. The state schools in the two zones are thirteen, while the Colleges of Education in the zones are thirty. This shows that the colleges are representative of the schools in those zones. Three state schools were selected using the simple random sampling; the 
schools are Tai Solarin College of Education, Ogun; Adeniran Ogunsanya College of Education, Lagos and College of Education, Cross Rivers. Furthermore, some state schools in the southern zones were excluded as a result of the restrictions to such states by the authorities of the University of Central Lancashire (Risk Assessment Form, UCLAN, 2012).

As earlier stated, a survey approach was used for this study. Forty English language students from each school completed the questionnaires that were administered using the stratified random selection. The students from each school were divided into two sets with twenty completing the questionnaires on the courses embodying the four language skills and twenty completing the other set on the implementation of the curriculum. Stratification was by years, as there are three levels in the colleges. The Year 1 students constituted the majority of students as the revised curriculum is implemented at that level presently (the Year 1 students constituted the majority because the implementation of the new curriculum does not embrace the existing Years $2 \& 3$ students). Simple random sampling was used to choose (36) 30\% students from Year 3, (30) 25\% from Year 2 and (54) 45\% from Year 1. Lecturers' questionnaires were administered to 20 lecturers from all the schools, while three lecturers from each school were also interviewed.

\section{Findings (Input Evaluation)}

This evaluation was conducted to examine the appropriateness of the course contents (with particular reference to courses embodying the four language skills), methodology, instructional materials and assessment. The data collected were from interviews and questionnaires. The researcher interviewed three lecturers from each school and twenty students from each school also completed the questionnaires. In accordance with the objectives of the input evaluation for this study, the data was analysed under the following headings: course contents, methodology, instructional materials and assessment (Chen, 2009) as shown in Table 3 below

\subsection{Course Contents}

Table 3. Course Contents and Organization

\begin{tabular}{|c|c|c|c|}
\hline & Frequency & Per cent & Total $\%$ \\
\hline \multicolumn{4}{|c|}{ 20. The course objectives are clear } \\
\hline $\begin{array}{l}\text { Strongly } \\
\text { Disagree }\end{array}$ & 2 & 3.3 & 3.4 \\
\hline Disagree & 6 & 10.0 & 13.6 \\
\hline Uncertain & 0 & 0.0 & 0.0 \\
\hline Agree & 26 & 43.3 & 57.6 \\
\hline $\begin{array}{l}\text { Strongly } \\
\text { Agree }\end{array}$ & 25 & 41.7 & 100.0 \\
\hline Total & 59 & 100 & \\
\hline Missing & 1 & 1.7 & \\
\hline \multicolumn{4}{|c|}{ 21. The course load is manageable } \\
\hline $\begin{array}{l}\text { Strongly } \\
\text { Disagree }\end{array}$ & 0 & 0.0 & 0.0 \\
\hline Disagree & 4 & 6.7 & 6.8 \\
\hline Uncertain & 13 & 21.7 & 28.8 \\
\hline Agree & 25 & 41.7 & 71.2 \\
\hline Strongly Agree & 17 & 28.3 & 100.0 \\
\hline Total & 59 & 98.3 & 100.0 \\
\hline Missing & 1 & 1.7 & \\
\hline \multicolumn{4}{|c|}{$\begin{array}{l}\text { 22. The courses are well organised (e.g. timely access to materials, notification of } \\
\text { changes etc.) }\end{array}$} \\
\hline $\begin{array}{l}\text { Strongly } \\
\text { Disagree }\end{array}$ & 3 & 5.0 & 5.3 \\
\hline Disagree & 4 & 6.7 & 12.3 \\
\hline Uncertain & 4 & 6.7 & 19.3 \\
\hline Agree & 26 & 43.3 & 64.9 \\
\hline $\begin{array}{l}\text { Strongly } \\
\text { Agree }\end{array}$ & 20 & 33.3 & 100.0 \\
\hline Total & 57 & 95.0 & \\
\hline Missing & 3 & 5.0 & \\
\hline
\end{tabular}

The data on the course contents of the courses embodying the four language skills indicate that more than half of the students $26(43.3 \%), 25(41.7 \%)$ and $26(43.3 \%)$ are of the opinion that the course objectives are clear, the course load is manageable and that the courses are well organized respectively. The analysis on the self-assessment of English skills by the students indicates that the students possess the four language skills. However, the interviews indicate that the lecturers varied in their judgements of the students' language levels. They rated them as excellent, average, above 
average and poor. It was asserted that in Adeniran Ogunsanya College of Education, the entry knowledge of the students is poor. This is also applicable to the College of Education, Akampka as the researcher observed during the administration of the questionnaires that a lecturer commented that the students could not defend their $\mathrm{O} /$ Level grades.

The lecturers in the three colleges also described the contents of the courses embodying the four language skills as suitable, appropriate, sufficient and adequate. In Adeniran Ogunsanya College of Education, it was noted that the new curriculum has been modified to meet the needs of pre-service and post- service teachers. In the College of Education, Akamkpa, the lecturers remarked that the response of the students and their lack of basic training are their deficiencies, while in the Tai Solarin College of Education, the lecturers identified deficiencies in the listening aspect of the course outline even though the curriculum has been recently reviewed. They remarked that this aspect was not emphasized and that it was abstract (in other words, it is not detailed and the contents are inadequate for the better understanding of the students).

\subsection{Methodology}

The views of the students were sought on the learning environment and teaching methods as shown below:

Table 4. Learning Environment and Teaching Methods

\begin{tabular}{|c|c|c|c|}
\hline & Frequency & Per cent & $\begin{array}{l}\text { Cumulative } \\
\text { Per cent }\end{array}$ \\
\hline \multicolumn{4}{|c|}{$\begin{array}{l}\text { 23. The learning and teaching methods encourage } \\
\text { participation }\end{array}$} \\
\hline \multicolumn{4}{|l|}{ Strongly } \\
\hline Disagree & 0 & 0.0 & 0.0 \\
\hline Disagree & 1 & 1.7 & 1.7 \\
\hline Uncertain & 5 & 8.3 & 10.0 \\
\hline Agree & 21 & 35.0 & 45.0 \\
\hline $\begin{array}{l}\text { Strongly } \\
\text { Agree }\end{array}$ & 33 & 55.0 & 100.0 \\
\hline Total & 60 & 100.0 & \\
\hline \multicolumn{4}{|c|}{ 24. Classrooms are Satisfactory } \\
\hline $\begin{array}{l}\text { Strongly } \\
\text { Disagree }\end{array}$ & 2 & 3.3 & 3.3 \\
\hline 2Disagree & 7 & 11.7 & 15.0 \\
\hline Uncertain & 10 & 15.0 & 30.0 \\
\hline Agree & 21 & 35.0 . & 65.0 \\
\hline $\begin{array}{l}\text { Strongly } \\
\text { Agree }\end{array}$ & 21 & 35.0 & 100.0 \\
\hline Total & 60 & 100.0 & \\
\hline \multicolumn{4}{|c|}{ 25. The overall environment is conducive to learning } \\
\hline $\begin{array}{l}\text { Strongly } \\
\text { Disagree }\end{array}$ & 2 & 3.3 & 3.3 \\
\hline Disagree & 5 & 8.3 & 11.7 \\
\hline Uncertain & 10 & 16.7 & 28.3 \\
\hline Agree & 18 & 30.0 & 58.3 \\
\hline $\begin{array}{l}\text { Strongly } \\
\text { agree }\end{array}$ & 25 & 41.7 & 100.0 \\
\hline Total & 60 & 100.0 & \\
\hline
\end{tabular}

The students $54(65 \%), 42(70 \%)$ and $43(71.7 \%)$ agreed /strongly agreed that the learning and teaching method encourage participation, classrooms are satisfactory and the overall learning environment is conducive respectively. This is however contrary to the minimum standards established by the curriculum as pictures reveal that two of the schools (College of Education, Akamkpa and Tai Solarin College of Education) do not utilize magnetic boards in their lecture theatres and classrooms. The methods of teaching adopted in class in the three schools according to the interviews are lecture, drama, assignments, presentation, group work, interactive, rapid learning approaches, rhymes, songs, cooperative learning, discussion, eclectic, brainstorming, project and seminar. In Adeniran Ogunsanya College of Education, the lecturers asserted that some of the benefits derived from adopting the methods are a lively class, participatory, knowledge impacted; teachers become facilitators and production of resources for other classes. The determinants of the methods adopted in class are time and situation, while in College of Education, Akamkpa, the determinant of the methods is the topic. The reasons for adopting these methods are to enhance assimilation, to develop the thinking skill of the students and to motivate them.

The interview data reveal that the lecturers in the three colleges suggested cooperative learning, which is participatory, discussion and eclectic methods as the most effective method. In Tai Solarin, the eclectic method was credited because 
it is suitable for different types of learners and its determinant is the assimilation of the students, while in College of Education, Akamkpa, the lecturers suggested discussion method as the most effective due to the fact that it encourages participation by students and reveals their problem areas. In the three colleges, there was a unanimous submission that the lecture method is the least effective. It was also remarked that the method is least effective due to its nature and technicality of some contents and that it does not encourage effective learning. In Tai Solarin College of Education, it was noted that the students prefer a combination of the lecture method with other methods of teaching.

\subsection{Instructional Materials}

The students also gave their opinion on the learning resources available in their schools

Table 5. Learning Resources

\begin{tabular}{|c|c|c|c|}
\hline & Frequency & Per cent & $\begin{array}{l}\text { Cumulative } \\
\text { Per cent }\end{array}$ \\
\hline \multicolumn{4}{|c|}{ 26. Recommended Reading Books are Relevant } \\
\hline $\begin{array}{l}\text { Strongly } \\
\text { Disagree }\end{array}$ & 0 & 0.0 & 0.0 \\
\hline Disagree & 1 & 1.7 & 1.7 \\
\hline Uncertain & 4 & 6.7 & 8.3 \\
\hline Agree & 22 & 36.7 & 45.0 \\
\hline $\begin{array}{l}\text { Strongly } \\
\text { Agree }\end{array}$ & 33 & 55.0 & 100.0 \\
\hline Total & 60 & 100.0 & \\
\hline \multicolumn{4}{|c|}{$\begin{array}{l}\text { 27. The provision of Learning Resources in the Library are } \\
\text { Adequate }\end{array}$} \\
\hline $\begin{array}{l}\text { Strongly } \\
\text { Diagree }\end{array}$ & 3 & 5.0 & 5.2 \\
\hline Disagree & 4 & 6.7 & 12.1 \\
\hline Uncertain & 9 & 15.0 & 27.6 \\
\hline Agree & 27 & 45.0 & 74.1 \\
\hline $\begin{array}{l}\text { Strongly } \\
\text { Agree }\end{array}$ & 15 & 25.0 & 100.0 \\
\hline Total & 58 & & \\
\hline \multicolumn{4}{|c|}{ 28. Learning Resources are Available in the Laboratory } \\
\hline $\begin{array}{l}\text { Strongly } \\
\text { Disagree }\end{array}$ & 4 & 6.7 & 7.0 \\
\hline Disagree & 5 & 8.3 & 15.8 \\
\hline Uncertain & 16 & 26.7 & 43.9 \\
\hline Agree & 21 & 35.0 & 80.7 \\
\hline $\begin{array}{l}\text { Strongly } \\
\text { Agree }\end{array}$ & 11 & 18.3 & \\
\hline Total & 57 & 95.0 & 100.0 \\
\hline
\end{tabular}

The students $55(91 \%), 42(70 \%)$ agreed/strongly agreed that the recommended reading books are relevant and the provision of learning resources are adequate respectively. However, 25 (41. 7\%) of the students do not agree that learning resources are available in the laboratory. This agreed with the lecturers' interviews, when they informed that the laboratory in one of the schools is not being utilized, the second is not properly utilized as a result of over-crowding, while the third school has no laboratory.

In Adeniran Ogunsanya College of Education, the criteria for the selection of textbooks are suitability, usefulness, prizes of books and their contents. The materials handed to students are lecture notes and online materials. In addition, the lecturers recommend foreign, local and books published by their colleagues to students. The resources employed in class are whiteboard, radio or tape recorder and charts. However, it was reported that in this particular college, the problem was practical as it relates to inadequate use of the language laboratory and lack of teaching materials exist, while in College of Education, Akamkpa, some of the processes that lead to choice of text are departmental agreement on preparation of monographs for the students, writing of monographs and their preparation by the school. The lecturers 
recommend and choose relevant texts too. It was suggested that the choice of texts should be based on availability and required standards. However, the problem is that lecturers have to source for texts that suit the understanding and abilities of the students.

In Tai Solarin College of Education, the lecturers also stated that some of the texts used by the students were recommended by NCCE. However, in the absence of that, the lecturers would have to choose texts and the criteria for such a choice would be affordability and usefulness. In this particular school, if the lecturer's choice would not be in the interest of the students, s/he would be given another option.

\subsection{Assessment}

The implementation Framework stipulates that for all the institutions, assessments should be based on (60:40) ratio. The assessment process comprises two stages:

i) $60 \%$ - Examination

ii) 40\%-Continuous Assessment

All courses are to be assessed on individual/group tests and written/practical tests. The tests are to measure skills and feedback is to be given to students at the end of each test within four weeks.

Table 6. Feedback on Assessment is within Four Weeks

\begin{tabular}{llll}
\hline 29. Feedback on Assessment is given within four weeks & & \\
\hline & Frequency & Per cent & Cumulative Per cent \\
\hline Strongly Disagree & 8 & 13.3 & 14.3 \\
\hline Disagree & 6 & 10.0 & 25.0 \\
\hline Uncertain & 13 & 21.7 & 48.2 \\
\hline Agree & 21 & 35.0 & 85.7 \\
\hline Strongly Agree & 8 & 13.3 & 100.0 \\
\hline Total & 56 & 93.3 & \\
\hline Missing & 4 & 6.7 & \\
\hline
\end{tabular}

Almost half the students $27(48.21 \%$ ) do not agree that feedback on assessment is given within four weeks, though 46 (76.6\%) concurred that the methods of assessment are appropriate.

\subsection{The Development of the Four Language Skills}

In Adeniran Ogunsanya College of Education, the lecturers reported that they teach all the skills, in other words, there is an integration of all the skills. The students develop the skills when they listen, write and read. The strategies for teaching the speaking skills are pronunciation of difficult words by students and the correction of their mistakes by the lecturer, while for the listening skills, the students listen to models, their lecturers, tape- recorded speeches and to one another.

In the College of Education, Akamkpa, the researcher noted that the four basic skills are taught separately and that the lecturers mentioned that the students develop the reading skill, when they read passages and respond to questions. In the Tai Solarin College of Education, students develop the reading skill, when they are exposed to reading errors and methods, the writing skill by writing and the speaking skill by engaging in speaking.

\section{Discussion}

\subsection{Research Question: How does the Implementation of the Curriculum Equip students to develop the four Language} Skills

\subsubsection{Course Contents}

The Curriculum prescribes that twenty two English language courses are to be offered during the entire programme. It also shows that twenty of the courses have compulsory status, with two being electives. The courses are mainly two credit courses, while few are one credit courses. Students who fail a course are expected to proceed to the next level, while repeating the course failed. The contents of the courses embodying the four language skills (as indicated during the interviews in 5.12.1) were described by the lecturers as suitable, appropriate, sufficient and adequate. They also informed that the new curriculum had been modified to meet the needs of pre-service and post service teachers. However, they were not fully satisfied with the listening aspect of the curriculum, which they described as being too abstract and lacking emphasis.

\subsubsection{Methodology}

The students were satisfied with the teaching methods adopted by the lecturers (e.g. they encourage participation) and the overall learning environment. However, their satisfaction with the learning environment is inconsistent with the stipulation of the Curriculum (Curriculum Implementation Framework, 2012) as Figures 5 and 6 show that two colleges do not utilize magnetic boards in their lecture theatres and classrooms. This may also be attributed to the desire of the students to protect the interest of their schools. 
The interviews also indicate that the lecturers unanimously proposed the lecture method as the least effective. Nevertheless, the method is still adopted in class; this corresponds with the findings of Legge (1971, Jarvis1995; cited in Badu-Nyarko \& Torto, 2014) that the use of the method by the lecturers may be justifiable as they have to deal with large classes. The "new curriculum recommends learner-centred approaches but the lecturers still use the traditional method of learning' (Bandele \& Faremi, 2012, p.16). This can be inferred from the interviews conducted with the lecturers that they employ the lecture method.

\subsubsection{Instructional Materials:}

The interviews show that the lecturers lack instruction materials as shown by the excerpts from one of the interviews. The lecturer was asked to comment on the specific needs of the students in relation to materials and the teaching resources adopted in class.

A lot of things are not available, so we have to improvise. The classrooms

are not the best kind of classrooms. There are situations, where we would

work better, if we had a projector. For us here, a projector is a dream.

\section{Interviewee 3-Tai Solarin College of Education.}

Chalkboard, sometimes the recording, unless we improvise and the charts.

At times, we go to class with laptops, if we have important information to

\section{pass on. Interviewee 3-Tai Solarin College of Education}

The study chimes with Abassah (2011) who reported the insufficient supply of instructional materials in technical Colleges of Education. It also concurs with Aromolaran (1985; cited in Umunadi, n.d). In a study conducted by Onyejemezie (2000, cited in Umar \& Ma'aji, 2010) on Quantity, Quality, Production and Distribution of Teaching Resources, it reported that the government does not support tertiary institutions with educational resources. The necessity of instructional facilities has been noted (Mkpa, 2000). Furthermore, the study corresponds with Ekpo, Udosen and Afangiadeh (2007, Olaniyan \& Obadara, 2008; cited in Agbatogun, 2013), who have associated the woeful teaching and learning process of the language in the country to the inadequacy of instructional materials. Similarly, an effective educational process in schools is a determinant of the adequacy of instructional materials and consequently, an enhancement of students' performance (Onyesom \& Okolocha, 2013).

\subsubsection{Assessment}

The implementation Framework stipulates that for all the institutions, assessments should be based on 60:40 ratio. The assessment process comprises two stages:

i) $60 \%$ - Examination

ii) $40 \%$ - Continuous Assessment

The Continuous Assessment would comprise an individual and a group exercise and also written and practical tests. Continuous assessment is of prime importance in the Nigerian educational system as the National Policy on Education emphasizes its relevance at all levels of education in the country (Aina \& Adedo, 2013). It motivates students (Adediran, Adelegun \& Balogun, n.d). The system ensures monitoring and measuring of a student's progress and the proper guidance as suited to each case (Ogar, 2007; cited in Aina \& Adedo, 2013). The practice of the system aids the establishment of students' progress. However, it has been asserted that continuous assessment concentrates on the cognitive domain at the expense of the affective and psychomotor domains (Yahaya \& Yamin, 2014). Other demerits of the practice are that it requires meticulous handling of students' records, which if negatively implemented would lead to failure of the students. Furthermore, the system strains the efforts of the lecturers as the data (see Section 7.2.2) demonstrates that the colleges are overcrowded. The collation of the marks of the students over a period of time demands more efforts by the lecturers.

The data demonstrates that the students are not given feedback on assessment within four working weeks as prescribed by the curriculum. This is an indication that the lecturers experience burnout in this aspect and it is a violation of the Minimum Standards on Assessments (Curriculum Implementation Framework, 2012). It has been noted by O'Farrell (n.d) that the timely provision of feedback to students will aid their application of such feedback and that it is good practice to give feedback within three weeks though more recent studies have demonstrated that 'timely' means early enough for the succeeding exercise. The questionnaires indicate that the Internal Quality Assurance Unit fails to monitor the lecturers. The Unit, which is supervised by a qualified lecturer (Curriculum Implementation Framework, 2012) has a measure of autonomy but lacks systemic failure of accountability. The reform provides that the Unit should regulate the monitoring, collation and storage of data on assessment. Moreover, the new curriculum labels assessment as 'pivotal'.

\subsubsection{Proficiency in the Four Language Skills}

The questionnaires show that the students are proficient in the four language skills. This counters the contention of Olaofe (n.d) that teachers lack proficiency in the four language skills. It is also inconsistent with the view that Colleges of Education students are non-proficient and incompetent users of English language (Obadare, 2011). However, interview data showed that the lecturers rated the students as excellent, average, above average and poor (see Section 5.11.1). An integrated approach to the teaching of the skills as asserted by the lecturers in Adeniran Ogunsanya College of Education concurs with earlier studies that have refuted the teaching of the four language skills through 'isolable 
discrete structural elements' (Corder, 1971, 1978; Kaplan 1970; Stern 1972 cited in Hinkel, 2010) and the view of Widdowson (1978 cited in Hinkel, 2010, p. 117) that 'language comprehension does not take place in discrete units'. Moreover, another advantage of integrated language skills is that the teaching of a skill separately as obtained in College of Education, Akamkpa would lead to a more purposeful and detailed teaching (Mcdonough \& Shaw; 2013, Widdowson, 1978, 1993; 2003 cited in Hinkel 2010).

However, as asserted by Hinkel (2010), the teaching of integrated skills in large classes may not be a feasible option as this has implication for Colleges of Education. Another disadvantage is that learners are not equally proficient in all the skills (Hinkel, 2002; 2003; Stern 1983 cited in Hinkel, 2010). Furthermore, integrated language teaching does not take cognizance of the learning product quality (Swan, 2005; Widdowson 1990; 2003 cited in Hinkel, 2010).

The analysis also shows that in Adeniran Ogunsanya College of Education, students develop the skills when they listen, write and read. This depicts an elementary strategy. The development of the skills through the aforementioned processes casts doubt on the communicative competence of the students. In addition, the development of the listening skill by simply listening suggests the environmentalist approach to listening. The development of the listening skill by adopting the contemporary method of teaching the skill as identified by Field $(2008$, p.17) would lead to a more purposeful development of the skills:

\section{Pre-Listening}

- $\quad$ Establish context

- Create motivation for listening

- Pre-teach only critical vocabulary

\section{Extensive Listening}

- General questions on context and attitude of speakers

Intensive Listening

- $\quad$ Pre-set questions

- Intensive listening

- Checking answers to questions

\section{Post listening (optional)}

- Functional language in listening passage

- Learners infer the meaning of unknown words from the sentences in which they appear

- $\quad$ Final play: learners look at transcript

The application of the format as given by Field (2008) is to teach 'critical words' (words which are very relevant in a passage). The lecturer should establish the context for the better understanding of the students. A way of creating motivation is to cause the students to predict what they would listen to by writing the title of the passage on the board. Pre-setting questions enables the students to listen for information and they can be allowed to check their answers, which can be done with the whole class. Students can infer vocabulary by working out the meaning of words they have listened to. The use of the format will enhance the understanding of the students. A final play may become necessary to reinforce what they had heard and the use of transcripts will further enhance their learning.

The development of the writing skill by writing suggests the process approach (Tribb1996). The use of the process genre approach as proposed by Badger and White (2000) would be appropriate. The development of the listening skill by the students through listening suggests that the listening skill is not actually taught in the colleges. The experience of the students is rather theoretical than practical. They are not appropriately assessed and taught the skill.

In addition, the interviews indicate that students develop the speaking skill, when they pronounce difficult words and their mistakes are corrected. These aforementioned strategies may not be really effective; a most probable process could be the following process as proposed by Thornbury (2005):

\section{Awareness Raising Activities}

- Awareness raising

- Using recordings and transcripts

- Focusing on some selected language features

- Using live listening

- Using noticing-the-gap-activities

Appropriation Activities

- Appropriation: practiced control

- Drilling and chants

- Reading aloud

- Assisted performance and scaffolding

- Dialogues

- Communicative tasks

- Task repetition

Towards Autonomy

- Autonomy and automaticity

- Criteria for speaking tasks 
- Feedback and correction

- Presentation and talks

- Stories, jokes and anecdotes

- Drama, role-play, and simulation

- Discussion and debates

- Conversation and chat

- Outside-class speaking

The application of the process as prescribed by Thornby (2005) will aid the acquisition of the skill by the students. Activities can be planned for the aforementioned process to enhance the teaching of the skill. Awareness raising will entail causing learners to pay attention, noticing and understanding a pattern. Learners can be made to study transcripts and recordings to raise awareness of a language's features. Lecturers can also sensitize the students on selected features of the language. The use of recordings will allow the detailed analysis of the features. To notice the gap means causing the learners to be aware of their deficiencies in the spoken language. Appropriation activities will enable the learners to master the spoken skills of the language by using all the methods listed under such activities. Towards autonomy promotes the ability of the learners to gain control of the skills the language by using the activities prescribed.

\section{Conclusion and Recommendations}

In conclusion, the study has shown that the students lack proficiency in the four language skills as the processes of teaching the skills are very elementary. The development of the skills is a pre-requisite for the attainment of the other objectives of the curriculum. The lecturers identified the entry knowledge of the students as a hindrance to the acquisition of the four language skills. It is therefore imperative that the Practical Listening Skills and Speech work aspect of the curriculum should be reviewed as the lecturers have noted its deficiency. The National Commission for Colleges of Education (NCCE) should enforce the provisions of the Minimum Standards as this will provide for adequate learning materials in the schools. Technological facilities should be provided, if learning materials must be in varied formats such as video, digital, internet etc. and access to the internet should be secured. This is a technological age, the traditional method of teaching that entails 'talk' and the 'use of the chalkboard' is no longer acceptable in this age, and therefore, the use of ICT in classroom teaching should be enforced.

The use of the language is a prerequisite for the attainment of fluency in it. The lecturers should adopt methodologies such as cooperative learning that promote learning. The use of the lecture method should be complemented with other teaching methods for effective teaching. The lecturers need to take cognizance of the social factors that impede the teaching and learning of the language in a social milieu (Brownson, 2012).

The students should explore other sources of learning the language as the classroom context is inadequate (Ugwanyi \& Omeje, 2012). The students should not have a negative attitude to their studies and they should cultivate reading culture (Tom-Lawyer, 2014). The new curriculum recommends that students should be enabled to take responsibility for their learning. This would require the exertion of effort by the students (Curriculum Implementation framework, 2012).

The collaboration of the parents and the college authorities, educational stakeholders and the government is a requisite for the better academic achievement of the students. The procurement of the necessary learning materials and books should be provided by parents. The students should not be made to fend for themselves while at school. Enlightened parents should encourage the students to communicate in the language. The parents should be involved in the academics of their wards. Some parents feel at this level, the students should no longer be monitored. This is a misgiving as the success of the students to an extent depends on the encouragement given by their parents.

\section{References}

Adekola, A. (2007). Language, literacy and learning in primary schools: Implications for teacher development programmes in Nigeria. Washington: The International Bank for Reconstruction and Development The World Bank.

Aduwa-Ogiegbaen,S \& Iyamu, O. (2006). Factors affecting quality of English Language teaching and learning in secondary schools in Nigeria. College Student Journal, 40(3) 495.

Agbatogun, A. (2013) Comparative effect of interactive Mobiles (Clickers) and Communicative Approach on the Learning Outcomes of the Educationally Disadvantaged Nigerian Pupils in ESL Classrooms (PhD Thesis, The University of Edinburgh, Scotland) Retrieved from https:/www.era.lib.ed.ac.uk/bitstream/ handle/1842/7932/ Agbatogun2013.pdf? sequence $=1$ \&isAllowed $=\mathrm{y}$

Ajeyalemi, D. (2005). Challenges of Teacher Education in Secondary Schools in Nigeria African Centre for Contemporary Studies. Paper Presented at a Two- Day National Workshop on the Counting Crisis of Secondary School in Nigeria: Confronting Old and New Challenges, 13-14 Sep. Retrieved from https://www.accs.org.uk/pdf/2005 /secondary/challenges_Of_Teacher20education. Accessed 16/02/13.

Akinbote, O. (2007). Problems for teacher education for primary schools in Nigeria: Beyond curriculum design and implementation. International Journal of African and African-American Studies.6 (2), 64-71.

Alkaff, A. (2013). Students' attitudes and perceptions towards Learning English. Arab World English Journal, 4(2) 106-121. 
Amaele, S. (2013). Menace of cultism in Nigeria Tertiary Institutions: Challenges and the Way forward. International Journal of Educational Foundation and Management, 1(1), 32-41.

Asiyai, R. (2013). Challenges of quality in higher education in Nigeria in $21^{\text {st }}$ century. International Journal of Educational Planning \& Administration, 3(2), 159-172.

Azubike, U. (1998). Language Teaching and Learning. Onitsha: Africana-First Publishers Limited.

Badger, R \& White, G (2000). A process genre approach to teaching. ELT Journal, 54 (2), 153-160.

Badu-Nyarko, S. \& Torto, B. (2014). Teaching methods preferred by part time tertiary students in Ghana. International Journal Humanities and Social Science, 4(1),226-233.

Bandele, S. \& Faremi, Y. (2012). An investigation into the challenges facing the implementation of technical college curriculum in the south-west, Nigeria. Journal of Education and Practice, 3(16), 14-20.

Brownson, E. (2012). Sociolinguistic consciousness and spoken English in Nigerian tertiary institutions. English language and Literature Studies, 2(4), 43-52.

Creswell, J. \& Clark, V. (2011). Designing and conducting mixed methods research USA: SAGE Publications, Inc.

Eveyik, E. (1999). Development of an attitude scale to investigate Turkish EFL teacher attitudes. Basilmamis Yuksek Lisam Tezi. Istanbul.

Eme-Uche, U. (2006). Constraints to teacher education in Nigeria: A study of the Nigeria Certificate in Education facilities, 862 (98.85), 10.

Federal Republic of Nigeria in Collaboration with International Labour Organization (ILO) Action Programme on Education, Teachers for the Future Meeting: Meeting Teacher Shortages to Achieve Education for All: National Policy Brief.

Federal Government of Nigeria (2012). Curriculum Implementation Framework for Nigeria Certificate in Education. Abuja: National Commission for Colleges of Education.

Field, J. (2008). Listening in the language classroom. Cambridge: Cambridge University Press.

Harmer, J. (2007). The practice of English language teaching. England: Longman.

Hedge, T. (2000). Teaching and learning in language classroom. Oxford University Press. Vol 106 Oxford: Oxford University Press

Hinkel, E. (2010). Integrating the four skills: Current and historical perspectives in R. B.Kaplan (Ed) Oxford Handbook in Applied Linguistics. Oxford University Press.

Ibidapo-Obe,O. (2007). The challenge of teacher education in Nigeria: The university of Lagos experience. A paper presented at the Second Regional Research Seminar for Africa, 1-11, UNESCO Forum on Higher Education, Research and Knowledge. Accra: Ghana.

Idoko, C. (2010). FG to scrap colleges of education. Retrieved from https:/groups.yahoo.com /neo/groups/Nigerian World /71136. Forum/conversations/messages Accessed 16/04/15.

Kwache, P. (2007). The imperatives of Information and Communication Technology for teachers in Nigeria higher education. MERLOT Journal of Online Learning and Teaching, 3(4).

Moja, T. (2000). Nigerian Education Sector Analysis: An Analytical Synthesis of Performance. New York: World Bank, $1-47$.

Olaofe, I. (n.d) Teacher resourcefulness in under resource English Language teaching- learning environments. Retrieved from http://www.natreslnigeria.org/natresl/papers/Teacher Resourcefulness.pdf

Omojimite, B. (2010). Education and economic growth in Nigeria: A granger Causality. African Research Review, 90 108

Onyesom, M \& Okolocha, C. (2013). Assessment of the adequacy of Instructional resources in Business education programmes relative to NCCE standards for Colleges of Education in Nigeria. Journal of Education and Learning, 2 (2), 165-178.

Patrick, J.,Sui, M.,Didam, B., Ojo, N. (2014). An insight into factors militating against Nigerian students attainment in English Language senior secondary certificate examination. Revista de Cercetare si Interventie Siciala, 45, $107-120$.

Stenhouse, L. (1975). An introduction to curriculum research and development. London: Heinemann.

Stufflebeam , D.\& Shinkfield, A. (2007). Evaluation theory, models and applications. San Francisco: Jossey-Bass

Thornbury, S. (2005). How to teach speaking. United Kingdom: Pearson Education Limited.

Yahya, S. \& Yamin, S. (2014) Difference and similarity of continuous assessment in Malaysian and Nigerian universities. Journal of Education and Practice, 5(1), 74-82. 